\title{
PSIKIYATRIK BELIRTILERLE BAŞLAYAN BİR NÖROAKANTOSITOZ OLGUSU
}

\author{
Okan Er , Erguvan Tuğba Özel Kızıl ${ }^{\star *}$, Zeynep Kuzu
}

\section{ÖZET}

Nöroakantositoz, kore, distoni, parkinsonizm ve tik gibi ekstrapiramidal nörolojik bulgular ve periferik kan yaymasında akantositoz ile nitelenen nörodejeneratif bir hastalıktır. Hastamız uzun yıllar farklı psikiyatrik tablolarla takip edilmiş ve sonrasında kliniğimizde nöroakantositoz tanısı konmuştur. Bu makalede nadir görülen bir tablo olan nöroakantositozun psikiyatrik semptomlarla başlayabileceğinin altını çizen bir olgu literatür bilgileri eşliğinde ele alınmıştır.

Anahtar Sözcükler: Nöroakantositoz, psikiyatrik belirtiler, orolingual diskinezi

\section{ABSTRACT}

Neuroacanthocytosis is a neurodegenerative disease, which consists movement disorders such as chorea, dystonia, parkinsonism and acanthocytosis in the peripheral blood smear. Our patient had been followed up with different psychiatric diagnoses and then he was diagnosed with neuroacanthocytosis. In this paper, a case with neuroacanthocytosis with psychiatric symptoms is described in the light of current literature.

Keywords: Neuroacanthocytosis, psychiatric symptoms, orolingual dyskinesia

Araş. Gör. Ankara Üniversitesi Tıp Fakültesi Ruh Sağlığı ve Hastalıkları Anabilim Dalı

Doç. Dr. Ankara Üniversitesi Tıp Fakültesi Ruh Sağıı̆ı ve Hastalıkları Anabilim Dalı

** Araş. Gör. Ankara Üniversitesi Tıp Fakültesi Nöroloji Anabilim Dalı

\section{Gíriş}

Nöroakantositoz, orofasiyal diskinezi, ekstremitelerde koreiform hareketler, dizartri, disfaji, kas atrofisi, arefleksi, epilepsi, kaslarda distalde belirgin atrofi ve güç kaybı, geç dönemde parkinsonizm ve demansın görülebildiği, labaratuar incelemelerinde periferik yaymada \% 3'ün üzerinde "akantosit" lerin eşlik ettiği, etyolojisinde heterojen bir grup hastalığın sorumlu tutulduğu multisistemik nörodejeneratif bir hastalıktır (Daroff 2012, Karakuş ve ark 2010, Kayahan 2005, Oğuz 2008, Türe 2006)

Yunanca "thorn" kelimesinden türeyen akantositoz terimi "diken" anlamına gelmektedir. Nöroakantositoz, Huntington Hastalığı'ndan sonra görülen herediter korenin en sık nedenidir. Olguların çoğu ailevidir (Rubio 1997). Neuroakantositozun genetik geçişi değişkenlik göstermekte olup heterojen olarak bulunabilen otozomal dominant (OD) ve otozomal resesif (OR) formları tanımlanmıştır (Rubio 1997). Otozomal resesif geçişte kromozom 9q21 lokusunda mutasyon gösterilmiştir ve bu genin ürünü olan korein proteini kusurludur (Rubio 1997).

Bu makalede nadir görülen bir tablo olan nöroakantositozun psikiyatrik semptomlarla 
başlayabileceğinin altını çizen bir olgu literatür bilgileri eşliğinde ele alınmıştır.

\section{OLGU}

38 yaşında, sağ elini kullanan, erkek hasta Ankara Üniversitesi Tıp Fakültesi Ruh Sağlığı ve Hastalıkları Polikliniği'ne kendi kendine konuşma, sosyal içe çekilme, uyku düzeninde bozulma, yürüme güçlüğü, konuşurken ve yemek yerken zorlanma, yüz, boyun ve ekstremitelerde istemsiz kasılma yakınmalarıyla başvurdu.

2004 yılına kadar belirgin bir şikayeti olmayan hastanın olumsuz ailevi bir olay sonrası başlayan sosyal içe çekilme, TV başında kendi kendine mırıldanarak konuşma, sinirlilik, kişilerarası ilişki sorunları ve alınganlık hali olduğu, bu yakınmalarının 2008 yııına kadar devam ettiği daha sonra dizartrisi, yürüme bozukluğu, yüz ve ekstremitelerdeki istemsiz kasılmalarının fark edilir hale geldiği öğrenildi. Hastanın işlevselliği belirgin olarak bozulmuş ve beraberinde istemsiz dudak Isırmaları sonucu bukkal mukozada yaralar oluşmuş. Hasta ilk kez mevcut şikayetleri ile 2009 yılında bir psikiyatri kliniğine başvurmuş. Hastaya davranış bozukluğu tanısıyla

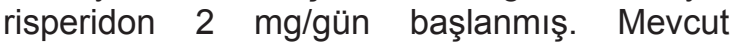
yakınmaları gerilemeyince tekrar hastaneye başvuran hastada distoni düşünülerek tedavi kesilmiş. Hastanın o dönem içerisinde bir kez jeneralize tonik klonik nöbeti olmuş. Yapılan Bilgisayarlı Beyin Tomografisinde ve kan tetkiklerinde sorun çıkmamış. Dissosiyatif Bozukluk ve Psikotik Bozukluk öntanılarıyla başka bir merkezde hastaneye yatışı yapılan hastanın biyokimya (BK), Tiroid Fonksiyon Testleri, Vit B12, folik asit, EEG, kraniyal MRG tetkiklerinde de herhangi bir patoloji saptanmamış. Hasta koopere olamadığı için psikometrik değerlendirme yapılamamış. Dissosiyatif bozukluk öntanısıyla risperdal $1 \mathrm{mg} / \mathrm{gün}$ tedavisine devam edilerek hasta taburcu edilmiş. Daha sonra mevcut tedaviden fayda görmeyen hastanın başka bir psikiyatri kliniğine başvurduğu ve Huntington hastalığı düşünülerek CPR istendiği ve normal sınırlarda bulunduğu da öğrenildi. 2011 yılında hastanın ağzındaki istemsiz kasılmalar giderek artmış; yemekleri sadece pipetle ve sıvı gıda şeklinde alabiliyormuş. Ağzındaki yaraların çok artması üzerine hasta başka bir merkezde Dermatoloji bölümünde oral liken planus öntanısıyla yatırılmış ve konsültasyon sonucu yapılan Çok yönlü Minesota Kişilik Envanteri'nde histerik özellikler saptanmıştır. Tedavisi paroksetin ve klonazepam şeklinde düzenlenmiş, ancak bu tedaviden fayda görmeyen hasta kliniğimize başvurmuştur.

Hastanın kliniğimizde yapılan muayenesinde orofasiyal diskinezi ve ekstremitelerde yaygın koreiform hareketleri olduğu, algı ya da düşünce bozukluğu bulunmadığı izlendi. Hastanın özgeçmişi ve soygeçmişinde özellik yoktu.

Nöroloji konsültasyonu sonucunda dizartrik, hipofonik ve nazone konuştuğu, derin tendon reflekslerinin dört ekstremitede hipoaktif olduğu, orofasiyal diskinezi ve ekstremitelerde koreiform hareketleri bulunduğu saptanarak Nöroakantositoz öntanısıyla laboratuvar incelemeleri yapıldı.

Hastanın tam kan, böbrek fonksiyon testleri, karaciğer fonksiyon testleri, tiroid fonksiyon testleri, B12 vitamin düzeyi testleri normal sınırlarda bulundu.

Yapılan periferik yaymasında yüzde yirminin üzerinde akantosit izlendi.

Resim 1: Olgunun periferik yaymasında akantositlerin görünümü

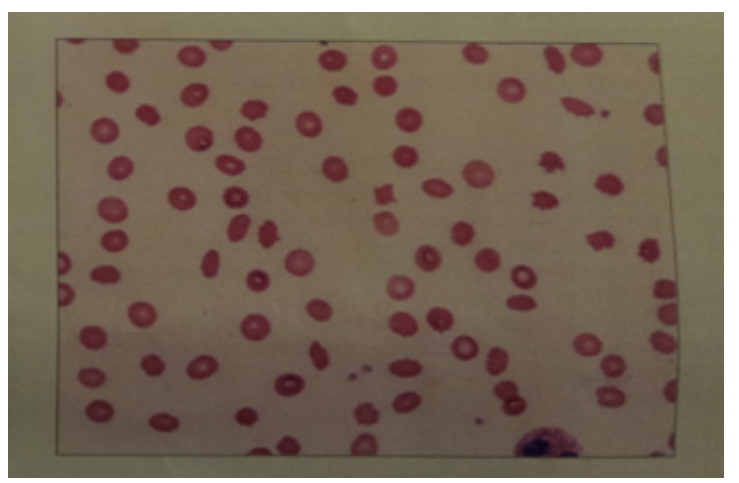

Hastanın çekilen Kranial MRG normal sınırlardaydı. 
Resim 2: Olgunun Kraniyel MR görüntülemesi

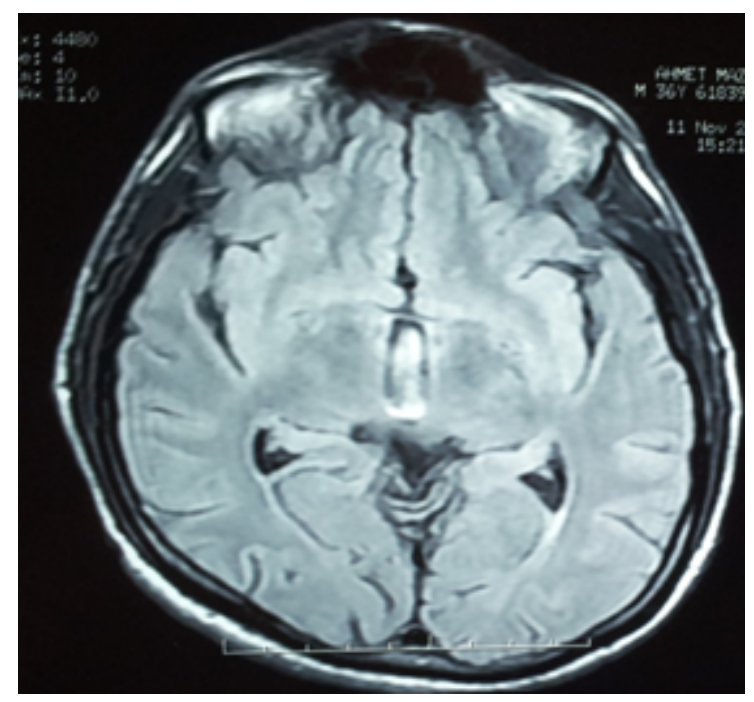

Hasta halen kliniğimizde Nöroakantositoz tanısıyla izlenmektedir. Hastanın ağız yaralarını engellemek için ağız apareyi önerildi. Hastaya lorezepam $2.5 \mathrm{mg} / \mathrm{gün}$ ve mevcut depresif duygudurum belirti ve bulguları için essitalopram $10 \mathrm{mg} / \mathrm{gün}$ tedavi olarak başlandı.

\section{TARTIŞMA}

Nöroakantositoz kore, orofasyolingual diskinezi, nöbet ve psikiyatrik bozukluklarla karakterize, periferik kanda "akantosit" olarak bilinen deforme eritrositlerin varlığı ile hareket bozukluklarının birarada olduğu etiyolojisi kesin olarak bilinmeyen nadir bir hastalıktır. Genellikle otozomal resesif geçişli olmakla birlikte otozomal dominant, X'e bağlı resesif ve sporadik vakalar bildirilmiştir (Luca ve ark 2002). Başlangıç genellikle 3 . dekatta olmakla birlikte her dekatta görülebilir, ortalama yaşam süresi kısalmıştır (Rafalowska ve ark 1996). Bizim hastamızda belirtilerin başlangıç yaşı 34 idi.

Nöroakantositozda tik, distoni ve akinetikrijid sendrom gibi farklı hareket bozuklukları görülebilmektedir. Kore $\% 85$, distoni $\% 50$, hiperkinetik yüz $\% 90$, istemsiz vokalizasyon $\% 62$, dizartri $\% 88$, disfaji $\% 62$, parkinsonizm bulguları \%32 oranında bildirilmiştir (Gökçay 2003, Hardie 1991, Türe 2006).
$\mathrm{Bu}$ olguda özellikle ekstremitelerde belirgin koreiform hareketler, yemek yemede ve konuşmada belirgin zorlanmaya neden olan orofasiyolingual diskinezi mevcuttu.

Nöroakantositozda epileptik nöbetler de sık olup, olguların \%40-50'sinde görüldüğü bildirilmektedir (Stevenson 2001, Adam 2004). $\mathrm{Bu}$ olguda da bir kez jeneralize tonik klonik nöbet öyküsü bulunmaktaydı.

Nöroakantositoz geniş bir psikiyatrik belirti yelpazesine sahiptir.Bilişsel işlevlerde bozulma, kişilik ve davranış değişikliği sıktır. Bununla birlikte anksiyete, paranoya, depresyon, obsesyon ve emosyonel labilite görülebilir (Stevenson 2001). Olguda sosyal emosyonel içe çekilme ve depresif yakınmalar ön plandaydı. Ayrıca olgunun olumsuz ailesel bir yaşantı sonrası başlayan belirtileri nedeniyle hekime başvurmuş olması, temelde nörolojik olan klinik tablonun psikiyatrik olarak değerlendirilmesine yol açmış olduğunu düşündürtmüştür.

Nöroakantositozlu hastaların yaklaşık yarısında nöropati rapor edilmiştir. Klinik olarak derin tendon refleksleri azalmıştır veya yoktur. Arefleksi oranı alt ekstremitelerde $\% 90$, üst ekstremitelerde \%85 olarak bildirilmiştir (Luca ve ark 2002). Hastamızda da derin tendon refleksleri azalmış olarak bulunmuştur.

Hastalığa spesifik olmamakla birlikte bilgisayarlı beyin tomografisi ve beyin MRG'de kaudat çekirdeklerde ve yaygın kortikal atrofi görülmektedir (Dervin ve ark 1991). Bu olguda belirgin atrofik değişiklik saptanmamıştır.

Nöroakantositozun ayırıcı tanısında kore, nörobilişsel bozukluklar ve psikiyatrik belirtilerle seyreden Huntington hastalığı düşünülmelidir. Ancak, Huntington hastalığı otozomal dominant geçişli olup, aile öyküsü tipiktir (Gold ve ark 2006, Rafalowska ve ark 1996). Dizartri ve disfajiye sebep olan orofasiyal diskineziler nöroakantositozu akla getirmelidir (Danek, Walker 2005). Ayrıca periferik kanda akantositoz saptanması tanı koydurucudur. Abetalipoproteinemi daha erken başlangıç yaşı, retinitis pigmentoza, serebellar ataksi ve 
serum lipoprotein elektroforezinde bozukluk olmasıyla nöroakantositozdan ayrılır (Rampoldi ve ark 2002).

Sonuç olarak, nöroakantositoz periferik yaymada akantositlerin görüldüğü, kliniğinde psikiyatrik belirtilerin ve hareket bozukluğunun izlendiği nadir görülen, multisistemik, nörodejeneratif bir hastalıktır. Dolayısıyla, atipik görünümlü hastalarda ve tedaviye yanıt alınamayan durumlarda akla getirilmesi gereken bir durumdur. Hastalığın kesin bir tedavisi olmamakla beraber, genetik geçiş açısından danışmanlık verilmesi önem arz etmektedir. 


\section{KAYNAKLAR}

Adam Z, Geoff S (2004) Neuroacanthocytosis. Practical Neurol, 4:298-301

Joseph J (2010) Movement Disorders, Chapter 71 .Bradley's Neurology in Clinical Practice, 6th ed.

Danek A, Walker RH (2005) Neuroacanthocytosis. Curr. Opin Neurol 18:386-392

Dervin JE, Kendall BK, Hardie RJ (1991) Neuroacanthocytosis: correlation of clinical and neuroimaging abnormalities. Neuroradiology 33 Supl:575-577.

Gold MM, Shifteh K, Bello JA, Lipton M, Kaufman DM, Brown AD. Choreaacanthocytosis (2006) : A mimicker of Huntington Disease Case Report and Review of Literature. The Neurologist. 12:327-329.

Gökçay F, Çolakoğlu Z. (2003) Koreakantositoz. Türk Nöroloji Der, 9(2):103-109.

Hardie RJ, Pulln HW, Harding AE et al (1991) Neuroacanthocytosis. A clinical, hematological and pathological study of 19 cases. Brain, 14:13-49.

Karakuş G, Tamam L, Uğur K, Tünel $M$, Özpoyraz N (2010) Farklı Psikiyatrik Görünümler Sergileyen Üç Nöroakantositoz Olgusu. Nöropsikiyatri Arşivi, 47: 356-9
Kayahan B, Özdemir F, Bora E ve ark. Nöroakantositozis (2005) Turkiye Klinikleri J Med Sci, 25:576-80.

Luca R, Adrian D, Anthony PM (2002) Clinical features and molecular basis of neuroacanthocytosis J Mol Med, 80:475-49.

Oğuz E, Özben S, Özer F ve ark. (2008) Nöroakantositoz:Olgu sunumu. Parkinson Hastalığı ve Hareket Bozuklukları Dergisi, 11:24-8.

Rafalowska J, Drac H, Jamrozik Z (1996) Neuroacanthocytosis. Review of literature and case report. Folia Neuropathol ,34(4):178-183.

Rampoldi L, Danek A, Monoca AP (2002) Clinical features and molecular bases of neuroacanthocytosis. J Mol Med, 80:475-491.

Rubio JP, Danek A, Stone C et al (1997) Choreaacanthocytosis: genetic linkage to chromosome 9q21. Am J Hum Genet, 61:899-908.

Stevenson VL, Hardie RJ (2001) Acanthocytosis and neurological disorders. J Neurol, 248:87-94.

Türe $\mathrm{S}$, Bilgin $\mathrm{R}$, Gedizlioğlu $\mathrm{M}$. Nöroakantositoz 2 olgu sunumu (2006) Parkinson Hastalığı ve Hareket Bozuklukları Dergisi, 9:38-43. 
